\title{
Intrauterine Fetal Loss Associated with Candida Glabrata Chorioamnionitis: Report of Two Cases
}

\author{
İntrauterin Fetal Kayıp ile İlişkili Kandida Glabrata Koryoamniyoniti: \\ İki Olgu Sunumu
}

\author{
Erdener ÖZER', Mehtat ÜNLÜ', Ayça ERŞEN' ${ }^{1}$, Bülent GÜLEKLi' ${ }^{2}$ \\ Departments of ${ }^{1}$ Pathology and ${ }^{2}$ Obstetrics and Gynecology, Dokuz Eylül University, Faculty of Medicine, IZMiR, TURKEY
}

\begin{abstract}
Chorioamnionitis is most commonly the result of an ascending infection caused by bacteria found within the lower genital tract. Yeast infections causing chorioamnionitis are very uncommon. Candida glabrata is a yeast that is considered to be a commensal of the vagina but vaginitis and rarely upper genital tract infection have been described. We report two cases of fungal chorioamnionitis occurring in pregnancies with a history of in vitro fertilization and cervical cerclage, both resulting in fetal loss. The histological features in conjunction with the positive cultures enabled C. glabrata to be identified as the causative organism producing severe chorioamnionitis. C. glabrata was probably introduced into the cervix at the time of embryo transfer, and during stitching the cervix. To prevent unfavorable outcomes in pregnant women, we recommend that vaginal and in particular cervical swabs should be taken prior to cervical procedures and appropriate treatment should be provided.
\end{abstract}

Key Words: Candida glabrata, Chorioamnionitis, Cervical cerclage, Fertilization in vitro

\begin{abstract}
ÖZ
Koryoamniyonitislerin büyük kısmı alt genital sistemde bulunan bakterilerin asendan enfeksiyonu sonucu gelişir. Mantar nedenli koryoamniyonitis enderdir. Kandida glabrata, vajende kommensal olarak bulunmakla birlikte nadiren vajinit ve üst genital sistem enfeksiyonuna yol açabilmektedir. Burada, in vitro fertilizasyon ile elde edilmiş, servikal serklaj uygulanmış ve fetal kayıp ile sonlanmış iki gebelikte saptanan fungal koryoamniyonitis olguları sunulmuştur. Histolojik özellikler ve pozitif kültür sonuçları ile koryoamniyonitis etkeni Kandida glabrata olarak saptanmıştır. Etkenin, embriyo transferi ve/veya servikal serklaj işlemi sırasında servikse ekilmiş olması muhtemeldir. Gebelere uygulanacak servikal işlemlerden önce vaginal ve özellikle servikal temizliğin sağlandığından emin olmak ve tedaviyi uygun planlamak bu tip istenmeyen sonuçları engelleyebilir.
\end{abstract}

Anahtar Sözcükler: Kandida glabrata, Koryoamniyonitis, Servikal serklaj, In vitro fertilizasyon

\section{INTRODUCTION}

Chorioamnionitis is a major cause of preterm rupture of membranes and preterm labour, and also a risk factor for perinatal morbidity and mortality. Numerous infectious agents leading to chorioamnionitis have been isolated. Most of these agents are bacteria (1). Fungal micro-organisms causing chorioamnionitis are very rare (1-3). Candida glabrata is the second most common Candida species. Its pathogenicity is limited in healthy hosts and it is considered a relatively nonpathogenic commensal microorganism of human mucosal tissue, especially in the vagina (4-6). We report here two cases of $C$. glabrata chorioamnionitis occurring in pregnancies, both resulting in fetal loss.

(Turk Patoloji Derg 2013, 29:77-79)

Received : 03.02.2011 Accepted : 24.03.2011

\section{CASE REPORTS}

\section{Case 1}

A 28-year-old woman, primagravida, with a dichorionicdiamniotic twin pregnancy presented at 17 weeks gestation with increasing vaginal bleeding over a 3-day period. She had undergone successful IVF and the transfer of two embryos secondary to male factor infertility, and she had an uncomplicated pregnancy until 15 weeks of gestation when one of the twins died in utero. She had pink vaginal discharge present since the beginning of pregnancy. However, a vaginal culture had not been obtained. Despite treatment with progesterone and antibiotics against gram negative bacteria, she developed preterm premature rupture of membranes and eventually delivered both fetuses at 18

Correspondence: Mehtat ÜNLÜ

Department of Pathology, Dokuz Eylül University, Faculty of Medicine, IZMMIR, TURKEY

E-mail: mehtat.unlu@deu.edu.tr Phone: +90 2324123415 
weeks gestation. At autopsy, examination of both fetuses revealed weights appropriate for gestational age and no malformations. The placentas were separate, weighing $120 \mathrm{~g}$ and $50 \mathrm{~g}$ respectively, and pathological examination of the placental membranes revealed severe acute inflammation and a large quantity of fungal organisms consistent with $C$. glabrata (Figure 1,2). There were no hyphae in any of the sections.

\section{Case 2}

A 29-year-old woman presented at 20 weeks gestation with increasing vaginal bleeding over a 2 -day period. She had had an uncomplicated pregnancy until 19 weeks of gestation. At that time cerclage was performed because of cervical

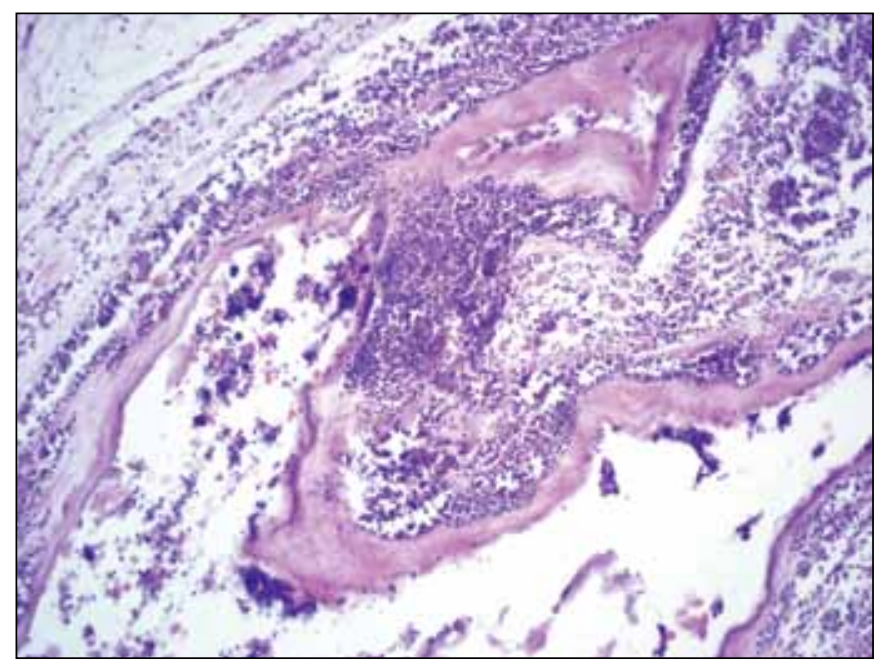

Figure 1: Placental membranes showing polymorph infiltrate and large colonies of yeast-like organism (H\&E, x40).

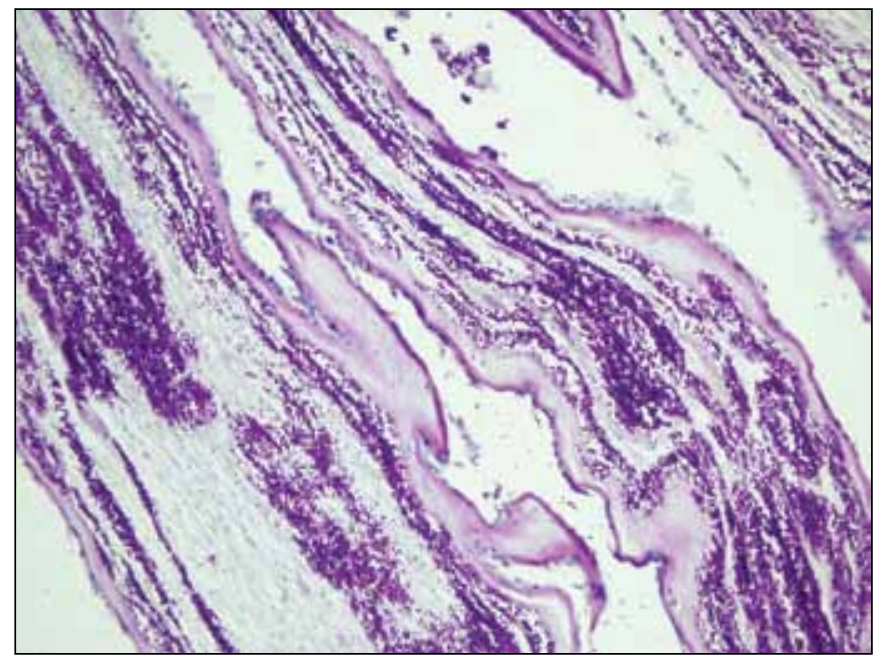

Figure 3: Placental membranes showing dense colonization by PAS positive yeast-like organism (PAS, x40). insufficiency. However, she developed preterm premature rupture of membranes and eventually delivered a stillbirth fetus at 21 weeks gestation. At autopsy, examination of stillbirth revealed normal growth and no malformations. The placenta weighed $200 \mathrm{~g}$ and histologically placental membranes revealed a severe polymorphous infiltrate. There were large sheets and multiple colonies of yeast-like microorganisms of variable size which stained positively with periodic acid-Schiff (Figure 3, 4). C. glabrata was cultured from both the excised umbilical cord and cervical cerclage material. The histological features in conjunction with the positive cultures enabled $C$. glabrata to be identified as the causative organism producing the severe chorioamnionitis.

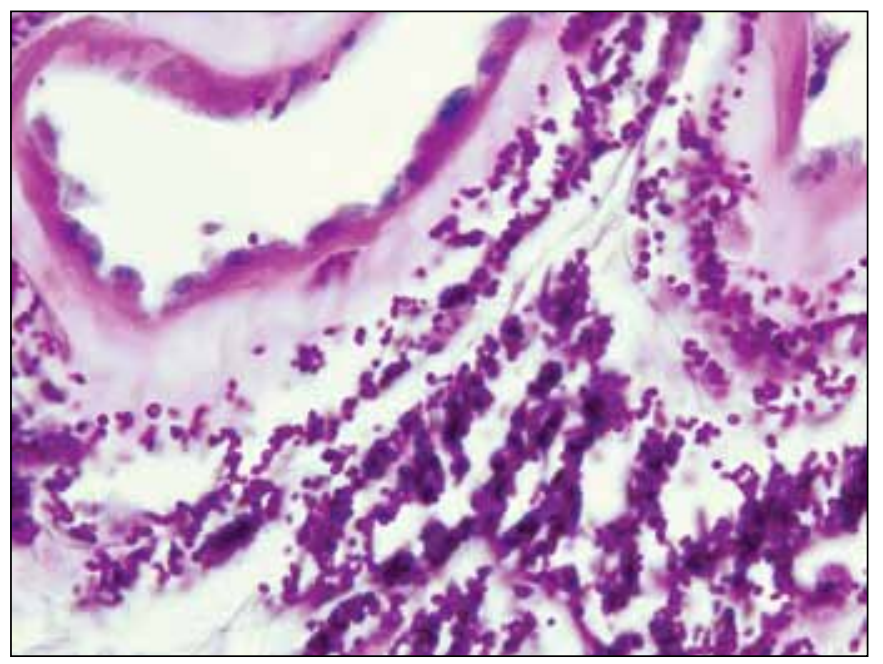

Figure 2: PAS positive yeast-like organism with high magnification (PAS, x100).

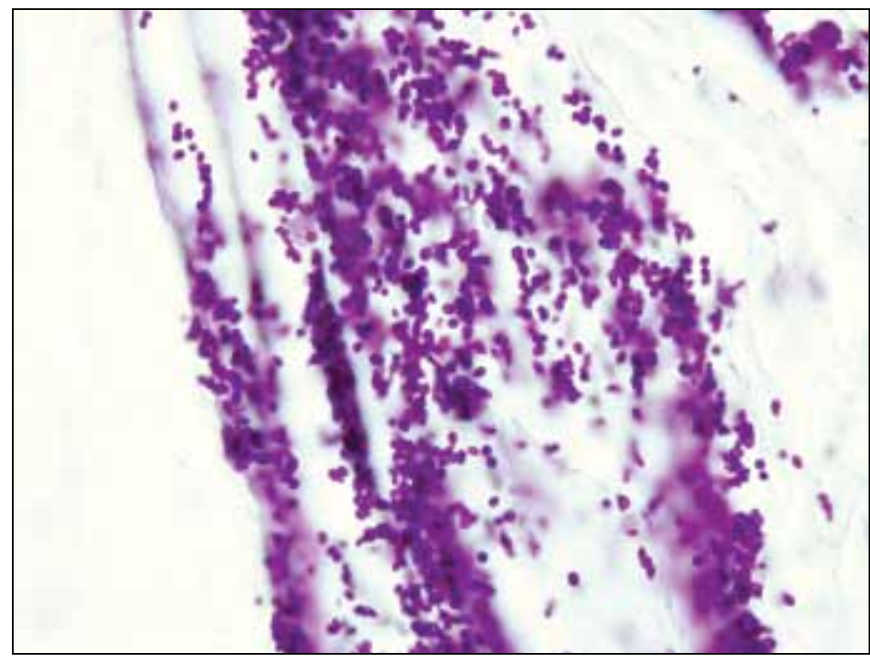

Figure 4: PAS positive yeast-like organism with high magnification (PAS, x100). 


\section{DISCUSSION}

Chorioamnionitis is a common complication of pregnancy associated with significant maternal, perinatal, and longterm adverse outcomes. It can be the cause of preterm labour, premature rupture of membranes and premature birth. The clinical diagnosis of chorioamnionitis may be difficult as only some gravidas have fever or uterine tenderness (1).

The fetal membranes most often become infected as a result of ascending infection from the vagina. Fungal infections are the rare cause of chorioamnionitis and congenital infections, and most of them are the result of C. albicans infection (13). C. albicans is the most common yeast isolated from the vagina in both symptomatic and asymptomatic patients, followed by $C$. glabrata and then by other uncommon species (7). Although C. glabrata has been considered saprophyte of the normal flora of the healthy individuals, it can cause mucosal (oropharyngeal, esophageal, vaginal) or systemic infections in immunocompromised hosts (4-7).

Laboratory experiments have demonstrated that C. albicans can readily infect and invade the fetal membranes in both blastospore and hyphal forms, although other Candida species studied, including C. glabrata, were not able to do so in vitro (8). Our report clearly demonstrates the ability of $C$. glabrata to cause a severe chorioamnionitis resulting in poor outcome. Intrauterine infection of this degree indicates that the infective process commenced from within the uterus rather than by the ascending route and this then raises the question as to how this microorganism could have gained access to the uterine cavity if haematogenous spread is excluded.

Candida albicans has been most commonly implicated, often in association with predisposing factors such as an intrauterine device or cervical cerclage $(9,10)$. Intrauterine yeast infection has also been diagnosed by amniocentesis when pregnancy is complicated by preterm labour or preterm rupture of the membranes. Microbial invasion of the amniotic cavity occurs frequently in women presenting with cervical dilatation in the midtrimester, and the amniotic cavity should therefore be considered before a cerclage is placed in women presenting with cervical dilatation in the midtrimester (10).
Foreign intrauterine bodies such as contraceptive devices and cerclage sutures necessitate repetitive search for Candida species infection, and prompt adequate antifungal treatment in cases of documented infection. In addition, vaginal and in particular cervical swabs should be taken prior to insertion of any cannula into the uterus for embryo transfer. If any pathogens are detected, the procedure should be deferred until treatment has been instituted and the micro-organism eradicated.

\section{REFERENCES}

1. Tita AT, Andrews WW: Diagnosis and management of clinical chorioamnionitis. Clin Perinatol 2010, 37:339-354

2. Roqué H, Abdelhak Y, Young BK: Intra amniotic candidiasis. Case report and meta-analysis of 54 cases. J Perinat Med 1999, 27:253-262

3. Barth T, Broscheit J, Bussen S, Dietl J: Maternal sepsis and intrauterine fetal death resulting from Candida tropicalis chorioamnionitis in a woman with a retained intrauterine contraceptive device. Acta Obstet Gynecol Scand 2002, 81: 981-982

4. Sfameni SF, Talbot JM, Chow SL, Brenton LA, Scurry JP: Candida glabrata chorioamnionitis following in vitro fertilization and embryo transfer. Aust NZ J Obstet Gynaecol 1997, 37:88-91

5. Fidel PL Jr, Vazquez JA, Sobel JD: Candida glabrata: Review of epidemiology, pathogenesis, and clinical disease with comparison to C. albicans. Clin Microbiol Rev 1999, 12:80-96

6. Ibara AS, Marcorelles P, Le Martelot MT, Touffet N, Moalic E, Hery-Arnaud G, Giroux JD, Le Flohic AM: Two cases of systemic Candida glabrata infection following in vitro fertilization and embryo transfer. Eur J Clin Microbiol Infect Dis 2004, 23:53-56

7. Khan ZU, Ahmad S, Al-Obaid I, Al-Sweih NA, Joseph L, Farhat $D$ : Emergence of resistance to amphotericin B and triazoles in Candida glabrata vaginal isolates in a case of recurrent vaginitis. J Chemother 2008, 20:488-491

8. Gurgan T, Diker KS, Haziroglu R, Urman B, Akan M: In vitro infection of human fetal membranes with Candida species. Gynecol Obstet Invest 1994, 37:164-167

9. Horn LC, Nenoff P, Ziegert M, Hockel M: Missed abortion complicated by Candida infection in a woman with rested IUD. Arch Gynecol Obstet 2001, 264:215-217

10. Romero R, Gonzalez R, Sepulveda W, Brandt F, Ramirez M, Sorokin Y, Mazor M, Treadwell MC, Cotton DB: Infection and labor. VIII. Microbial invasion of the amniotic cavity in patients with suspected cervical incompetence: prevalence and clinical significance. Am J Obstet Gynecol 1992,167:1086-1091 